\title{
The Management of Village Fund Finances
}

\author{
Inten Meutia ${ }^{\bowtie}$, Liliana \\ Faculty of Economics, Universitas Sriwijaya, Indonesia \\ Jl. Raya Palembang - Prabumulih Km. 32 Indralaya, OI, Sumatera Selatan 30662, Indonesia
}

DOI: http://dx.doi.org/10.15294/jda.v9i1.12009

Received: 30 October 2016. Revised: 24 December 2016. Accepted: 28 February 2017. Published: 31 March 2017

\begin{abstract}
The purpose of this research is to know the implementation of fund management of village fund in Ogan Ilir Regency, South Sumatera. The population in this study were 224 villages in Ogan Ilir Regency that received the allocation of Village Funds in 2016. The purposive sampling technique was applied to obtain samples and produce 26 villages. The analysis will be carried out with a quantitative and qualitative description process. Based on the data obtained, the researcher tries to describe or describe systematically, accurately, and factually about matters relating to the field as fact, nature, and relationship between phenomena. Quantitative techniques will also use frequency analysis that aims to provide an overview of the general condition. The results reveal that the financial management aspects are generally in accordance with those set out in Permendagri 113/2014 and have complied with the basic principles of financial management. Reporting and accountability remain a problem for some villages. Not all of the villages studied have aspects of human resource reporting and accountability. Taking into account the composition of village budgeting, the village does not meet the rules that require a ratio of 70:30, this results in inequality in the implementation of rural development. The conclusion of this research is that the implementation of village fund management in Ogan Ilur Regency has been running well according to Permendagri 113/2014.
\end{abstract}

Keywords: Village Fund; Village Plan; Financial Management

How to cite (APA 6th Style)

Meutia, I. \& Liliana. (2017). The Management of Village Fund Finances. Jurnal Dinamika Akuntansi, $9(1), 63-81$.

\section{INTRODUCTION}

Governance which directly connects with rural communities becomes an important focus in government development, due to the territory of Indonesia mostly located in rural areas. The existence of Law Number 6/2014 which discusses about the village then in setting the authority of the village is given the flexibility, the authorities assigned based on the right of origin, authority in the local context of the village scale, and other authorities in accordance with the provisions assigned by the government. Law No. 6/2014 which discusses villages as relatively new instruments issued by the government which is followed up with Government Regulation No. 43/2014 which discusses the Implementation of Law No. 6/2014 which describes Village and Government Regulation No. 60/2014 which explains the Village Fund which funded from the state budget. The philosophy of village fund is to improve the welfare of rural communities and the equitable distribution of development conducted in village with improved public services, advanced village

Inten Meutia $(\bowtie)$

E-mail: inten26@yahoo.com 
economic, reducing development gaps between village and strengthening village communities not only as objects but acting as subjects in the development. Based on Government Regulation No. 60/2014, the priority of Village Fund utilization in development and empowerment for rural community. Minister of Village, Disadvantaged Areas Development, and Transmigration establish the priorities of rural community development and empowerment activities. In the Year 2015 the government disbursed the Village Fund amounted to Rp. 20.766 trillion and Year 2016 amounted to $\mathrm{Rp} 46.9$ trillion for all villages in Indonesia. This amount is more than twice the funds disbursed in 2015.

The enactment of the laws has consequences which has enabled the village government to obtain funds which can be managed relatively big. On the other hand, the relatively large funds must be managed and accounted for well. To that end, the government has also prepared several related regulations to support the accountability of the Village Fund. Government Regulation Number 60/2014 which discusses the Village Fund (funding source from APBN) which is updated with Government Regulation No. 22/2010 of the Minister of Home Affairs Regulation No. 113/2014 which discusses Village Financial Management. The regulations above are not intended to make it difficult rural governments to manage the Village Funds, but to be maximally utilized for the sake of rural progress and can be accounted for as well as possible. On the other hand, resource constraints may be an obstacle for rural governments to manage according to the rules and objectives of establishing a Village Fund. Considering that the Village Fund policy is still relatively new and there has not been much research done to see the implementation of this policy, while for a new policy needs to be evaluated. Therefore, how the readiness and use of the Village Fund is an interesting thing to be studied. Hence, this study focuses on the issue of how the accountability for the management of the Village Funds both in the form of budget and realization. This research aims to know the implementation of financial management village funds.

In general, there have not been many studies that have looked at the Village Fund since this topic is relatively new. Nevertheless, there are several studies related to Village Fund Allocation (ADD) that try to see its management from the role of human resources. With regard to funding sources, there is a difference between the Village Fund and the Village Fund Allocation (ADD). The results of the research about the implementation related to the Fund Allocation program (Suparman, Kusnadi, \& Harono, 2014) find several things that have an effect on the success of ADD program implementation to empower rural community such as factors of human resource, socialization in fund allocation, the existence of coordination has not yet in accordance with the expectation and desire so that in its implementation, ADD does not run optimally. Effectiveness in Village Fund Allocation to alleviate poverty (Azwardi \& Sukanto, 2014) find that the ADD distributed were not in accordance with the existing provisions. As of 2012 in South Sumatra province, the distribution of funds that has been undertaken has not been fulfilled in accordance with the stipulated requirements (at least ten percent of funds originating from revenue sharing and added with taxes achieved and reduced by personnel expenditures). The presence of regions in the distribution of ADD has increased, if in the year 2006 amounted to $35.71 \%$ then in the year 2012 has increased to $90 \%$. The reasons stated, the existing regulations do not or have not yet sanctioned for areas that do not distribute ADD. Village Fund Allocation Management (Thomas, 2013) in an effort to improve the development done in Sebawang village, Sesayap Subdistrict finds the low level of human resources of village apparatus and the lack of coordination related to the management of ADD are the most perceived obstacle in the process of managing the Village Fund allocation.

The effectiveness of Village Fund Allocation management (I Wayan Saputra, 2016) in Lembean Village, Kintamani Subdistrict, Bangli District The year is in effective category, because the effectiveness level of each year is $90 \%-100 \%$ (effective). The effectiveness level of each year is 2009 (98.89\%), 2010 (100\%), 2011 (100\%), 2012 (89.24\%), 2013 (100\%) and 2014 (99.57\%). Local Wisdom of Pade Gelahang In Achieving Accountability Integration of Subak Organization 
Financial Management (Darmada, Atmadja, \& Sinarwati, 2016) find that financial management in Subak Delod Sema, Penarukan village does not involve all krama subak, but only involving some prajuru subak and krama who become committee in every activity in subak. Those parties namely, Kelihan Subak/Pekaseh, Penyarikan/ Secretary, Petengen/ Treasurer, Kelihan Tempekan/ Head of Section and krama appointed as committee in Ngusaba Village ceremony or other activities in subak. Review on Village Financial Implementation in Supporting Village Fund Policy (Abidin, 2015) finds that village autonomy then there will be village financial management. Village financial management requires the existence and completeness of the village apparatus. The provinces of East Java and Central Java are the provinces with the lowest percentage of village secretary position, 82.83 percent and 82.85 percent, respectively. Availability of village secretaries in other provinces is still below 85 percent: West Kalimantan, Bangka Belitung Islands, Riau Islands and East Nusa Tenggara.

Village Autonomy and Village Fund Effectiveness (Nyimas Latifah Letty Aziz, 2016) finds that there are various obstacles in the distribution and use of the Village Fund such as the low capability and capacity of the Village Government's human resources and the active participation in village communities which is very minimal in the process of distributing the existing Village Funds. At present, village funds still face obstacles. This incident is a natural thing because the Village Fund is a new program that requires improvement in the process by looking at the situation in the field. Constraint of low capability and capacity of local government human resources, especially for the Village Government causes a delay in the process of the Village Fund distribution in 2015. Analysis of mechanisms in distributing the Village Fund Allocation (Darmiasih, Sulindawati, \& Darmawan, 2015) find things done related to the subject matter among others: (1) The mechanism of the Village Fund Allocation distribution in Tri Eka Buana Village has been received by the Village Government from the Central Government, which is incorporated into the Village Budget (APBDesa). (2) The management of the Village Fund Allocation has been referred to the Regent Regulation Number 28/2011 on the Implementation Guidelines for the Management of Village Fund Allocation described the mechanism of distribution of the Village Fund Allocation in the Village Budget (APBDesa). The researches that have been conducted have not yet studied further the linkages between Village Fund and the issue of food independence, the development of natural resources, and the sustainable environment in accordance with the Minister of Village Regulation No. 5 / 2015. So what will be studied in this study is expected to increase the study of Village Fund and enrich policies to be taken in relation to the Village Fund.

\section{METHODS}

This study focuses on Ogan Ilir District of South Sumatra. The scope of this study is to analyze the accountability implementation of Village Fund management as well as its relationship with food independence as well as natural resources and the living environment. There are 224 villages in Ogan Ilir District receiving Village Fund allocations. The total amount of village funds received by Ogan Ilir District for 2016 is Rp 137,920,919,000. Total revenue increased more than doubled from Year 2015 amounting to Rp 61,530,628,000, -. The analysis will be carried out with a quantitative and qualitative description process. Based on the data obtained, the researcher attempts to describe or illustrate systematically, accurately, and factually about matters relating to the field as facts, traits, and relationships between phenomena. Quantitative techniques will also use frequency analysis that aims to provide an overview of the conditions in general. To further draw conclusions based on existing data on how accountability of financial management performance of Village Fund in Ogan Ilir District of South Sumatera and its relation with food independence and sustainable natural and environmental resources development.

The use of data obtained and utilized is in the form of primary and secondary data types. Source in obtaining data by survey and interviewing directly to the related parties as the power holder of the village financial management such as village head, village secretary, head of affairs, 
village treasurer and other village officials the implementer of village activities. Interviews and indept interviews were conducted in August and Setember 2016. Subdistricts in Ogan Ilir District are 16 sub-districts consisting of 227 villages and there are 14 kelurahans. The primary data collection is done by using purposive sampling technique (respondent is someone who is well inform person-WIP or the most knowledgeable person related to the management of Village Fund) with target consists of 26 villages through interview with the help of questionnaire. Survey method is done by interview with questionnaire guidance which is closed and open. Secondary data obtained from BPMPD of Ogan Ilir District, Development Planning Agency at Sub-National Level (Bappeda), Central Bureau of Statistics, and other relevant agencies.

\section{RESULTS AND DISCUSSIONS}

State Budget (APBN) was a source of funding for Village Funds intended for villages that could be transferred through district or city Budget and used in funding for governance, implementation in development, guidance, and empowerment for the community. It further stated that village development sought to improve the quality of life of improving welfare for rural communities. While empowerment done for the village community tried to develop self-reliance and welfare of society through improvement of knowledge, behaviour, awareness, attitude, skill, ability, and resource utilization by setting activity, program, and policy, and also assistance which needed to be adjusted to the essence of the problem and priority needs for rural communities. Village funds might be used for the development and empowerment of village communities. The use of Village Funds was prioritized for the development of villages with the allocations that were used in achieving the objectives of village development namely improved welfare and quality of life and could overcome poverty by meeting basic needs, development and infrastructure, potential local economic development and sustainable natural and environmental resources management. Based on the program / activity, it was hoped that the program / activity which its implementation was related to the objective aspect of the village development.

Priority of Village Fund utilization related to development for village facilities and infrastructure based on the situation and potency in the village, as the target of Medium-term Development Plan (RPJM) and Village Government Work Plan (RKP Desa) each year was achieved. The Village Fund, which funding sources were derived from state budget (APBN) in empowering villagers to overcome poverty and increase access to economic resources. PMK No. 49/2010 which regulated the procedures for allocation, distribution, utilization, monitoring and evaluation. It was explained that related to aspects of administration, accounting and financial reporting carried out in accordance with the provisions in the legislation. Minister of Home Affairs Regulation Number 113/2014 was the regulation of the Minister of Home Affairs which regulated the Village Financial Management which consisted of planning, implementation, administration, reporting, and financial accountability. Village finances should be managed on the basis of governance principles with the principles of accountability, transparency, participation and must be orderly and discipline with budgets. The Village Fund was the source of income obtained by the village from the transfer group. The Village Fund was a source of revenue derived from the state budget. Village budget expenses as a result of village expenditure required a draft in relation to village regulations that discussed village budgets established in village regulations. Head of Village must make report to Bupati or Mayor at the end of fiscal year. To ensure accountability in village financial management it must be regulated in various clear regulations.

Village Funds in the Province of South Sumatera in 2016, where each village would receive a basic allocation fund of $\mathrm{Rp} 565,640,000$, - added with the allocation of the formula namely based on the large number of villagers, the number of poor, area extent, and Geographical Expense Index (IKG). The average per village would receive Rp. 628.000.000, -. Regulation of the Minister of Village or Permendes Number 5/2015 which regulated the utilization of Village Funds with various priorities on the development that undertaken by the village with the allocation in 
realizing the objectives of village development through improving welfare and living standard and tackling poverty by meeting basic needs, development of facilities and infrastructure, potential local economies development and utilization of sustainable natural and environmental resources. As for the details that have obtained the Village Fund for 14 districts and there was one city in South Sumatra Province for the Year 2015 and 2016 where each of Rp 775,043,818,000 and $1,780,769,519,000$. The largest allocation of funds was in Lahat regency from Rp 95,317,372,000 to Rp 213,827,592,000 in 2015 and the smallest city was Prabumulih amounting to $R p 5,251,221,000$ in the same year and Pali district in the amount of Rp 11,835,161,000 in 2016, a thorough explanation could be described in table 1 .

Table 1. Fund Village in South Sumatra in 2015 and 2016

\begin{tabular}{lllll}
\hline $\begin{array}{c}\text { Name of Dis- } \\
\text { trict/ City }\end{array}$ & $\begin{array}{c}\text { Allocation of } \\
\text { Fund Village } \\
(\mathrm{Rp}) 2015\end{array}$ & Rank & $\begin{array}{c}\text { Allocation of } \\
\text { Fund Village (Rp) } \\
2016\end{array}$ & $\begin{array}{c}\text { Number } \\
\text { of Village }\end{array}$ \\
\hline Lahat & $95,317,372,000$ & 1 & $213,827,592,000$ & 360 \\
Banyuasin & $80,574,536,000$ & 3 & $180,639,025,000$ & 288 \\
Empat Lawang & $41,475,592,000$ & 10 & $93,091,712,000$ & 153 \\
Muara Enim & $67,422,614,000$ & 5 & $151,239,875,000$ & 245 \\
Ogan Ilir & $62,825,270,000$ & 7 & $115,125,323,000$ & 186 \\
Musi Rawas & $51,324,892,000$ & 9 & $54,024,213,000$ & 82 \\
Muratara & $24,083,445,000$ & 12 & $137,920,919,000$ & 224 \\
Ogan Ilir & $61,530,628,000$ & 8 & $209,805,972,000$ & 314 \\
OKU Timur & $81,680,235,000$ & 2 & $47,604,942,000$ & 65 \\
OKI & $80,128,511,000$ & 4 & $88,382,767,000$ & 143 \\
OKU Selatan & $67,322,758,000$ & 6 & $183,223,802,000$ & 305 \\
OKU & $39,402,354,000$ & 11 & $150,992,910,000$ & 252 \\
PALI & $16,704,390,000$ & 13 & $11,835,306,000$ & 15 \\
Prabumulih & $5,251,221,000$ & 14 & $143,055,161,000$ & 227 \\
$\quad$ Total & $775,043,818,000$ & & $1,780,769,519,000$ & 2859 \\
\hline \multicolumn{5}{c}{ Source :BPS, 2015 }
\end{tabular}

Ogan Ilir District was divided into 227 villages and there were 14 kelurahans. The widest area was in Rambang Kuang Subdistrict which had area of $528.8 \mathrm{Km} 2$, Indralaya Utara Subdistrict with area of $502.5 \mathrm{Km} 2$, and Muara Kuang Subdistrict with area of $300.75 \mathrm{Km} 2$, while which had the smallest area was Rantau Panjang Subdistrict namely $40.9 \mathrm{Km} 2$. The densest population was in Tanjung Batu Subdistrict with a total of 47,773 inhabitants and Tanjung Raja Subdistrict with a total of 45,769 inhabitants, the smallest population was in Kandis Sub-district with 10,883 inhabitants and West Pemulutan Subdistrict with 14,395 inhabitants.

Based on the information from the Head of BPMPD OI informant, until May 2016, the Village Governmental Community Empowerment Board (BPMPD) of Ogan Ilir has disbursed the first phase of fund village sourced from the state budget (APBN) reached Rp 82 billion more or about 60 percent of the Ogan Ilir Village Fund allocation in 2016 amounted to Rp 137 billion. BPMPD asked each village to utilize the Village Fund as best as possible for the progress of village development. The second term would be disbursed at the end of 2016. According to the Head of BPMPD OI, the disbursement of the Village Fund was a central government aid dedicated to village development that was adapted to the needs of the village. In addition to the Village Fund sourced from the central, his party has also disbursed the allocation of Village Fund of Ogan Ilir 
District sourced from Regional budget (APBD) Year 2016 amounted to Rp 9 billion.

Furthermore, Table 2 described the amount of Village Funds that existed in each subdistrict in Ogan Ilir District. In total, Ogan Ilir District received the Village Fund for 2016 amounting to Rp 137,920,919,000. In the Year 2016 the funds were spread across 16 districts or 227 villages in the Ogan Ilir District. The largest village fund was in Pemulutan Subdistrict, which was Rp $15,662,571,000$ with a total of 25 villages receiving beneficiaries and Tanjung Batu Subdistricts with the amount of $\mathrm{Rp} 11,561,883,000$ and 19 villages receiving beneficiaries. The smallest village fund was in Muara Kuang Subdistrict worth Rp 6,169,636,000, - for 10 villages, there were 3 villages which were not included in the attachment of permendagri. It increased twice from 2015 only amounted to $\operatorname{Rp} 61,530,628,000$ with the smallest village fund in Lubuk Keliat Subdistrict amounted to $\operatorname{Rp} 2,780,423,000$.

Table 2. Data of Fund Village in 2015 - 2016 per Subdistrict in Ogan Ilir

\begin{tabular}{|c|c|c|c|}
\hline Subdistrict & $\begin{array}{l}\text { Number } \\
\text { of Village }\end{array}$ & $\begin{array}{l}\text { Fund Village of } \\
\qquad 2015\end{array}$ & $\begin{array}{l}\text { Fund Village of } \\
2016\end{array}$ \\
\hline Muara Kuang & 13 & $3,523,893,000$ & $6,169,636,000$ \\
\hline Tanjung Batu & 19 & $5,075,580,000$ & $11,561,883,000$ \\
\hline Payaraman & 11 & $2,959,286,000$ & $6,732,139,000$ \\
\hline Tanjung Raja & 15 & $4,048,508,000$ & $9,202,256,000$ \\
\hline Indralaya & 17 & $4,594,648,000$ & $10,440,453,000$ \\
\hline Lubuk Keliat & 10 & $2,780,423,000$ & $6,286,466,000$ \\
\hline Pemulutan & 25 & $6,924,926,000$ & $15,662,571,000$ \\
\hline Rantau Alai & 13 & $3,469,247,000$ & $7,903,250,000$ \\
\hline Rambang Kuang & 13 & $3,448,631,000$ & $7,865,946,000$ \\
\hline Indralaya Utara & 15 & $4,051,677,000$ & $9,211,119,000$ \\
\hline Indralaya selatan & 14 & $3,730,566,000$ & $8,500,846,000$ \\
\hline Kandis & 12 & $3,199,196,000$ & $7,289,309,000$ \\
\hline Pemulutan Selatan & 15 & $4,081,145,000$ & $9,262,739,000$ \\
\hline Pemulutan Barat & 11 & $2,999,466,000$ & $6,804,666,000$ \\
\hline Rantau Panjang & 12 & $3,320,076,000$ & $7,510,836,000$ \\
\hline Sungai Pinang & 12 & $3,323,360,000$ & $7,516,804,000$ \\
\hline Total & 227 & $61,530,628,000$ & $137,920,919,000$ \\
\hline
\end{tabular}

Meanwhile, BPMPD Operational Officer of Ogan Ilir District, Sulaiman explained that the disbursement of Village Fund had several stages covering the stages from the state treasury to the regional treasury based on the regent's regulation and the enactment of the district budget (ABPD Kabupaten) and the requirement to propose the village development work plans. "There were 4 activities that must be done namely in the field of government, empowerment, development and community, but more priority on empowerment and development Yes, if in Ogan Ilir District tended to build roads, bridges and educational facilities," he said. 
Table 3. Recap of Environmental Development Activities

\begin{tabular}{|c|c|c|c|c|c|c|}
\hline \multirow[b]{2}{*}{ Subdistricts } & \multicolumn{6}{|c|}{ Activities } \\
\hline & $\begin{array}{c}\text { Clean } \\
\text { Water } \\
\text { Facility }\end{array}$ & Toilet & $\begin{array}{c}\text { Siring } \\
\text { Develop- } \\
\text { ment }\end{array}$ & $\begin{array}{l}\text { Retaining } \\
\text { Wall Con- } \\
\text { struction }\end{array}$ & $\begin{array}{l}\text { Channel } \\
\text { Normali- } \\
\text { zation }\end{array}$ & $\begin{array}{c}\text { River } \\
\text { DAM } \\
\text { Dumps }\end{array}$ \\
\hline Indralaya Selatan & 3 & 2 & 3 & 3 & & \\
\hline Tanjung Raja & 3 & 3 & 9 & 1 & & \\
\hline Lubuk Keliat & & & 3 & & & \\
\hline Kandis & & & 2 & 1 & & \\
\hline Indralaya & 2 & 1 & 5 & 2 & & \\
\hline Pemulutan & 2 & 3 & & 1 & & \\
\hline Pemulutan Barat & 1 & 4 & & & & \\
\hline Pemulutan Selatan & & 4 & & & & \\
\hline Rantau Panjang & & & & 2 & & \\
\hline Inderalaya Utara & & & 3 & & 2 & 1 \\
\hline Sungai Pinang & 1 & 1 & & & & \\
\hline Muara Kuang & 1 & 1 & 6 & & & \\
\hline Payaraman & & & 13 & 1 & & \\
\hline Rambang Kuang & 1 & & 3 & 1 & & \\
\hline TOTAL & 14 & 19 & 47 & 12 & 2 & 1 \\
\hline
\end{tabular}

Source : BPMPD of Ogan Ilir, 2016

Respondents in this case were those who were considered to have sufficient and adequate knowledge about the management of the Village Fund. From 26 respondents of the research, 50 percent or 13 respondents were the village heads. The position of the village secretary as many as 8 people (31\%), 1 person (4\%) was the village treasurer. While 4 people $(15 \%)$ were other village officials who were implementing village activities.

Table 4. List of Villages That Became Research Objects

\begin{tabular}{llll}
\hline Village & Subdistrict & Village & Subdistrict \\
\hline Tanjung Lalang & & Tanjung Harapan & \\
Sri Kembang III & & Ulak Kerbau Baru & \\
Lubuk Bandung & Payaraman & Belanti & \\
Rengas II & & Talang Balai Baru & Tanjung Raja \\
Sri Kembang I & & Tanjung Raja Selatan & \\
Sungai Buaya & Pemulutan & Ulak Kerbau Lama & \\
Pelabuhan Dalam & Indralaya Utara & Kerinjing & \\
Tanjung Seteko & & Arisan Jaya & Pemulutan Barat \\
Sk Tiga Sebrang & & Tebing Gerinting & \\
Tanjung Sejaro & & Tbg Gerinting Utara & Indralaya Selatan \\
Penyandingan & Indralaya & Tanjung Lubuk & \\
Muara Penimbung & & Kapuk & Pemulutan Selatan \\
Lubuk Sakti & & Payakabung & Indralaya Utara \\
\hline
\end{tabular}


The data obtained from the field, the majority of respondents' education (50\%) had education at elementary to high school, then there were 2 respondents (8\%) who had education at $\mathrm{D} 3$ or $\mathrm{D} 4$ level. The respondents who had undergraduate level (S1) as many as 10 people (38\%) and only 1 respondent (4\%) who had S2 education. Institutions in the village government still faced constraints related to village head capacity and village officials which were relatively low. This would relate the capacity of village human resources in managing the government, especially village finances with programs that should be done to encourage the acceleration of welfare for the community.

Table 5. Respondents' Education

\begin{tabular}{lcc}
\hline Respondents' Education & Number & Percentage \\
\hline Elementary School (SD) up to High School (SMA) & 13 & $50 \%$ \\
D3 up to D4 & 2 & $8 \%$ \\
S1 & 10 & $38 \%$ \\
S2 & 1 & $4 \%$ \\
Total & 26 & $100 \%$ \\
\hline
\end{tabular}

\section{Use of Village Funds intended for Village Development}

Minister of Village Regulation No. 5 of 2015 in Article 5 explained in detail about the priority of the use of Village Funds that may be used for the purpose of development and empowerment of rural communities. The priority of the use were to meet basic needs, development of facilities and infrastructure, development of potential local economic, management of natural and environment resources that was sustainable.

\section{Priority 1: Fulfilment of Basic Needs}

Table 6 below showed the priority of the use of the Village Fund in relation to meet basic needs. From 26 villages that became research objects there were two villages (8\%) used the Village Fund to develop village health posts and Village Maternity Home or Pondok Bersalin Desa (Polindes), namely Belati Village and Tanjung Harapan Village. Meanwhile, 24 villages (92\%) did not use the Village Fund for the development of village health posts and polindes. This was due to in other villages the village health post already existed. For the management and guidance of integrated servise or pos pelayanan terpadu (posyandu) activities only 9 villages (35\%) allocated their village funds for the management and guidance of posyandu. The Management and Development was done in the form of providing supplementary food to posyandu participants which was done regularly. Meanwhile, the other $65 \%$ did not allocate funds to activities related to the guidance of posyandu in the village. This was for according to the sources, they already had other funding sources to support various posyandu activities in their village.

Regarding to guidance and management of early childhood education (PAUD) activities which was one of three activities related to the fulfilment of basic needs, only 3 villages (12\%) used their village funds for the development and guidance of early childhood education such as Arisan Jaya, Payakabung and Sungai Buaya Village. Meanwhile, 23 other villages (88\%) did not allocate funds for the management and guidance of early childhood education in the village. 
Table 6. Fulfilment of Basic Needs

\begin{tabular}{lccc}
\hline \multirow{2}{*}{ Explanation } & \multicolumn{3}{c}{ Answer } \\
\cline { 2 - 4 } & Yes & No & Total \\
\hline Development of health pos and Polindes & $2(8 \%)$ & $24(92 \%)$ & $26(100 \%)$ \\
Management and guidance of Posyandu & $9(35 \%)$ & $17(65 \%)$ & $26(100 \%)$ \\
Guidance and management of PAUD & $3(12 \%)$ & $23(88 \%)$ & $26(100 \%)$ \\
\hline
\end{tabular}

Source: Research Data, 2016

In the three villages that used their funds for the guidance and development of early childhood education due to they opined that early childhood education still needed to be assisted because it did not have enough facilities yet. Meanwhile, other villages which did not allocate funds for early childhood because according to the villages that became sample in this study, there were 23 villages ( $88 \%$ ) allocated who were interviewed not all villages had early childhood education, or because the early childhood education in the village had been running well enough so that the priority of village funds use were used for other activities that they thought were more prioritized.

\section{Priority 2: Development for village facilities and infrastructure.}

Table 7. below showed the use of the Village Fund for facilities and infrastructures development activities. From 26 villages that became sample in the study, there were 23 villages $(88 \%)$ which allocated village funds to develop and maintain village roads. Only 3 villages (12\%) which did not allocate their village funds for village road development, namely Arisan Jaya Village, Payakabung and Rengas II. Later, for the construction and maintenance of farm roads only 6 villages (23\%) did it and 20 villages $(77 \%)$ did not do.

Table 7. The Development of Village Facilities and Infrastructures

\begin{tabular}{lccc}
\hline \multirow{2}{*}{ Explanation } & \multicolumn{3}{c}{ Answer } \\
\cline { 2 - 4 } & Yes & No & Total \\
\hline Construction and maintenance of village roads & $23(88 \%)$ & $3(12 \%)$ & $26(100 \%)$ \\
Construction and maintenance of farm roads & $6(23 \%)$ & $20(77 \%)$ & $26(100 \%)$ \\
Construction and maintenance village embungs & $1(4 \%)$ & $25(96 \%)$ & $26(100 \%)$ \\
Construction and maintenance of environmental sanitation & $14(54 \%)$ & $12(46 \%)$ & $26(100 \%)$ \\
Construction and maintenance of clean water (village scale) & $4(15 \%)$ & $22(85 \%)$ & $26(100 \%)$ \\
Construction and maintenance of irrigation (tertiary) & $1(4 \%)$ & $25(96 \%)$ & $26(100 \%)$ \\
\hline
\end{tabular}

Source: Research Data, 2016

The most resident of the villages that built or maintained the farm road were farmers. Meanwhile, in the construction and maintenance of the village embungs only one village (Tanjung Harapan Village) that allocated for the construction and maintenance of the village embungs and the rest did not allocate. In the construction and maintenance of environmental sanitation such as ditch construction, construction of landslide retaining walls on the riverbanks and others there were 14 villages (54\%) that undertook the construction and maintenance of environmental sanitation and the remaining 12 villages (46\%) did not undertake the construction and maintenance of environmental sanitation in 2015. The development and management of clean water at village level such as drilling wells to fulfil village clean water need was done by 4 villages namely Tanjung Sejaro, Tanjung Harapan, Arisan Jaya and Tanjung Balai I. Meanwhile, 22 other villages did not manage and build clean water facilities in the Year of 2015. Then, there was the development and maintenance of tertiary irrigation done by one village that was Arisan 
Jaya Village and the rest 25 did not do the development or management of irrigation.

\section{Priority 3: Development of local economic potency}

Table 8 below illustrated the use of the Village Fund for potential local economic development activities. From 13 activities that were activities related to the development of local economic potency only five activities existed or conducted by the village that became the sample in this study. These activities were: 1) Establishment and development of Village owned enterprises; 2) making fertilizer and feed (organic) 3) Development and management of Village market or stall; 4) development and management of village granary; 5) technology development (processing of agricultural and fishery products). From the total 26 villages surveyed, there were 3 villages that developed and established the Village Owned Enterprise (BUMDes) namely Lubuk Bandung, Payakabung, and Pairing as one of the villages ways to increase income from the village business itself, while the other 23 villages did not have and develop their Village Owned Enterprise (BUMDes) in 2015. Then, for the development and management of village granary, only 1 village did it, Arisan Jaya Village and 25 other villages had not or did not develop or manage the village granary. There was one village that hold activities of making organic fertilizer for agriculture with the help of Sriwijaya University that was Ulak Kerbau Baru Village. When further explored in connection with this activity, it turned out that the activities undertaken were still limited to the provision of training. However, informants in the village said that in the future they intended to make this activity as one of the priorities for their village, and expected continuous coaching and training so that the results of this program could be seen and felt by the villagers. The development of appropriate technology for the management of agricultural and fishery products have also been done by one village, Ulak Kerbau Lama Village.

Table 8. The Development of Local Economic Potency

\begin{tabular}{|c|c|c|c|}
\hline \multirow{2}{*}{ Explanation } & \multicolumn{3}{|c|}{ Answer } \\
\hline & Yes & No & Total \\
\hline $\begin{array}{l}\text { Establishment and development of Village-owned } \\
\text { enterprises }\end{array}$ & $3(12 \%)$ & $23(88) \%)$ & $26(100 \%)$ \\
\hline $\begin{array}{l}\text { Making fertilizer and feed (organic) for agriculture } \\
\text { and fishery }\end{array}$ & $1(4 \%)$ & $25(96 \%)$ & $26(100 \%)$ \\
\hline $\begin{array}{l}\text { Development and management of village markets or } \\
\text { village stall }\end{array}$ & $1(4 \%)$ & $25(96 \%)$ & $26(100 \%)$ \\
\hline $\begin{array}{l}\text { Construction and management of fish auction sites } \\
\text { (owned by villages) }\end{array}$ & - & $26(100 \%)$ & $26(100 \%)$ \\
\hline Development and management of village granary & $1(4 \%)$ & $25(96 \%)$ & $26(100 \%)$ \\
\hline Development of local seeds & - & $26(100 \%)$ & $26(100 \%)$ \\
\hline Development of cattle collectively & - & $26(100 \%)$ & $26(100 \%)$ \\
\hline $\begin{array}{l}\text { Development and management of independent } \\
\text { energy }\end{array}$ & - & $26(100 \%)$ & $26(100 \%)$ \\
\hline Construction and management of boat moorings & - & $26(100 \%)$ & $26(100 \%)$ \\
\hline Pasture management & - & $26(100 \%)$ & $26(100 \%)$ \\
\hline Tourism Village Management & - & $26(100 \%)$ & $26(100 \%)$ \\
\hline $\begin{array}{l}\text { Development of appropriate technology for the } \\
\text { processing of agricultural and fishery products }\end{array}$ & $1(4 \%)$ & 25 (96\%) & $26(100 \%)$ \\
\hline
\end{tabular}

Source: Research Data, 2016 


\section{Priority 4: Sustainable Environmental Resources Utilization.}

Table 9 provided an overview of how much village government's attention to activities related to sustainable environmental resources utilization. In relation to the sustainable environmental resources utilization, from all the villages that became the object of the study has not been yet one village using the Village Fund for such activities as mandated in Minister of Village Regulation no. 5/2015. This was according to the informant that the village head because the area of Ogan Ilir was not mining area such as Lahat or Tanjung Enim and also not a coastal area so it has the potency to cultivate seaweed. According to the informant in this study they have not considered it important and did not really know the right program to allocate village funds for these activities, besides they also said fear if the misuse of funds happened which would have legal consequences for them so they were more careful in the allocation of fund.

Table 9. The Utilization of Sustainable Natural and Environment Resources

\begin{tabular}{lccc}
\hline \multirow{2}{*}{ Explanation } & \multicolumn{3}{c}{ Answer } \\
\cline { 2 - 4 } & Yes & No & Total \\
\hline Non-metal mineral mining commodities & - & $26(100 \%)$ & $26(100 \%)$ \\
Rock mining commodities & - & $26(100 \%)$ & $26(100 \%)$ \\
Seaweed & - & $26(100 \%)$ & $26(100 \%)$ \\
Forest belongs to the village & - & $26(100 \%)$ & $26(100 \%)$ \\
Waste management & $1(4 \%)$ & $25(96 \%)$ & $26(100 \%)$ \\
\hline \multicolumn{2}{c}{ Source: Research Data, 2016 } \\
\end{tabular}

As for the development of new and renewable energy, the development and maintenance of aquaculture, and the development of production facilities and infrastructure in the village there was no one village that allocated their Fund Village for this activity. This showed that the development of new and renewable energy has not been a priority for them. From the result of interviews to informants, most of them did not yet understand what new and renewable energy was. When given examples of forms of renewable energy they considered it not to be a priority. Although, they realized that someday this would be important but not now. Another thing according to them was more activities that became development priorities in villages more important than new and renewable energy. If the government considered it important according to some informants there should be projects / activities from the government in the form of other funds.

\section{Priority to Use Village Funds for Villager Empowerment.}

Minister of Village Regulation in Article 5 set that Village Fund may be used to empower the villagers. Table 9 below illustrated the priority of the use of Village Funds in particular in relation to villagers' empowerment. From the seven activities related to the empowerment of villagers, all the activities were undertaken by villages except for activities that supported village programs and communities of village forest management and community forestry. Activities to improve the quality in village planning process were conducted by 18 villages (10 people). This meant that villages paid great attention to activities aimed at empowering villagers. In relation to village support to the development of Village-owned enterprises and community business groups, only 5 villages did. This happened due to there were still a few villages that had Village Ownership Enterprises (BUMDes). Regarding to the capacity establishment and building of cadres empowerment there were only 3 villages that allocated their funds. The same case happened for paralegal facilitation activities in providing legal assistance to villagers conducted by 3 villages. Empowerment in organizing promotion about health and clean and healthy life movement was done by 4 villages that organized the activities were Sri Kembang I, Ulak Kerbau 
Lama, Payakabung, and Tanjung Harapan Villages.

Table 10. The Priority of the Use of Fund Village for Villagers Empowerment

\begin{tabular}{lccc}
\hline \multirow{2}{*}{ Explanation } & \multicolumn{3}{c}{ Answer } \\
\cline { 2 - 4 } & Yes & No & Total \\
\hline Improved quality of village planning process; & 18 & 8 & 26 \\
& $(69 \%)$ & $(31 \%)$ & $(100 \%)$ \\
Capacity establishment and building of cadre in villagers' empower- & 3 & 23 & 26 \\
ment; & $(12 \%)$ & $(88 \%)$ & $(100 \%)$ \\
$\begin{array}{l}\text { Supporting economic activities developed by Village-owned enter- } \\
\text { prises or other villagers business groups; }\end{array}$ & 5 & 21 & 26 \\
& $(19 \%)$ & $(81 \%)$ & $(100 \%)$ \\
Organizing health promotion activities and clean and healthy life & 4 & 22 & 26 \\
movements; & $(15 \%)$ & $(85 \%)$ & $(100 \%)$ \\
Organization through the formation and paralegal facilitation in pro-- & 3 & 23 & 26 \\
viding legal assistance; & $(12 \%)$ & $(88 \%)$ & $(100 \%)$ \\
Capacity building of community groups & 8 & 18 & 26 \\
& $(30 \%)$ & $(70 \%)$ & $(100 \%)$ \\
\hline
\end{tabular}

Source: Research Data, 2016

Afterwards, for the activities that supported the activities and communities of village forest management, none of the villages did it because there was no village had village forest. Furthermore, the last was the capacity building of community groups, from 26 existing villages, there were 8 villages that were improving the capacity of the village groups. From the existing data, it could be concluded that the priority of villager empowerment was one of the priorities undertaken by the village with the Village Fund they got. The empowerment conducted was mainly related to the improvement of village planning quality. This indicated that the village has realized that good planning would be a good guide in carrying out the development process in the village. Thus, it was expected that the development process in the village would take place effectively and in accordance with the development plan expected by the government.

\section{Financial Management.}

Minister of Home Affairs Regulation or Permendagri Number 113 Year 2014 regulated on the Village Financial Management which covering all activities starting from Planning, Implementation, Administration, Reporting, and Financial Accountability. This study more saw the financial management aspects of the Village Fund from the side of implementation, administration, reporting, and accountability. In relation to the implementation aspect, Articles 24 and 27 stipulated several matters to ensure that the implementation of financial management was carried out in accordance with principles such as accountable, transparent, participatory principles which were carried out with discipline and budgetary order in accordance with the mandate of Article 2 of Permendagri 113 of 2014. Table 10 below illustrated the aspects of financial management performed by all the villages that became the object of this research.

\section{Implementation}

The implementation of financial management conducted in the village that became the object of this research has been in accordance with what was regulated in the Minister of Domestic Affairs Regulation No. 113/2014. In the implementation, all village expenditures and revenues have been using village accounts and have been completed with valid documents. The submission of activities was accompanied by a Budget Plan (RAB) which was verified and approved by the 
village secretary. All the activities have been using cash assistance books. All the activities above have been done well by all the villages. This showed that the implementation aspect of financial management carried out by 26 villages that became the object of research in general could be said good because it has complied with the basic principles of financial management.

Table 11. The Implementation of Financial Management

\begin{tabular}{|c|c|c|c|}
\hline \multirow{2}{*}{ Explanation } & \multicolumn{3}{|c|}{ Answer } \\
\hline & Yes & No & Total \\
\hline $\begin{array}{l}\text { Village revenue and expenditure (using cash account of the } \\
\text { village). }\end{array}$ & $26(100 \%)$ & - & $26(100 \%)$ \\
\hline Village revenues and expenditures completed by evidence. & $26(100 \%)$ & - & $26(100 \%)$ \\
\hline $\begin{array}{l}\text { The submission of activities accompanied by a Budget Plan } \\
\text { (RAB). }\end{array}$ & $26(100 \%)$ & - & $26(100 \%)$ \\
\hline $\begin{array}{l}\text { The Village Secretary verified RAB and Village Head } \\
\text { validated it. }\end{array}$ & $26(100 \%)$ & - & $26(100 \%)$ \\
\hline $\begin{array}{l}\text { Accountability in the implementation of village activities } \\
\text { using the Cash Assistant Book of Activities }\end{array}$ & $26(100 \%)$ & - & $26(100 \%)$ \\
\hline
\end{tabular}

Source: Research Data, 2016

\section{Administration}

Related to the administration aspect, there were two things that must be fulfilled namely the use of cashbook and accountability report. With regard to Cash book there was only one village that did not have a Bank Book, Tax Benefits Cashbook, and General Cashbook namely Kapuk Village because they have not been informed and trained either formally or informally for such financial management activities. Meanwhile, other villages have completed the administration in the management of these finances. With regard to the accountability report of village treasurers, all the villages have made accountability reports.

Although then it became a question of how villages that did not have a bank book, tax auxiliary cash book, and general cash book could prepare an accountability report. After being searched further, the village concerned instead of not having bank book, tax auxiliary cash book, and general cash book just the way the recording was still not separated and traditionally incorporated in a book. This was due to the limitations or knowledge of implementers and they have not understood the importance of administration. Therefore, in the future, supportive training was required in developing the capacity of village officials.

Table 12. Administration Activities

\begin{tabular}{llccc}
\hline \multirow{2}{*}{ No } & Explanation & \multicolumn{3}{c}{ Answer } \\
\cline { 2 - 4 } & & Yes & No & Total \\
\hline A & $\begin{array}{l}\text { Administration of receipts and expenditures } \\
\text { made using }\end{array}$ & & & \\
& Bank Book & $25(96 \%)$ & $1(4 \%)$ & $26(100 \%)$ \\
& Tax Auxiliary Cash book & $25(96 \%)$ & $1(4 \%)$ & $26(100 \%)$ \\
& General Cash book & $25(96 \%)$ & $1(4 \%)$ & $26(100 \%)$ \\
B & The treasurer took account of money through & $26(100 \%)$ & - & $26(100 \%)$ \\
& an accountability report & & &
\end{tabular}

Source: Research Data, 2016 


\section{Reporting and Accountability}

With regard to the accountability report of village treasurers, all the villages have made accountability reports. Although the way of recording was still not separated and traditionally incorporated in one book. This was due to the limitations or knowledge of implementers and they have not understood the importance of administration. With respect to reporting, the village head had an obligation to deliver the realization report in the implementation of Village Budget to the Regent or Mayor which covering the Realization Report of the Village Budget Implementation in the First Semester and the Final Semester. Data on Reporting and Accountability carried out by villages that became the object of this research for more details saw table 13.

From 25 villages that became the object of the research, there were 23 villages that made realization report each semester, while the other three villages have not done it each semester. The three villages were Tanjung Seteko, Ulak Kerbau Lama and Kerinjing Villages. The reason for these three villages not to make a realization report per semester in the given time was due to the limited human resources. According to the village head who became informant, there was no village staff had the capacity to manage finances. Furthermore, regarding the Village Property Wealth Report of 25 villages that became the object of this research, only 18 villages which made the report. The rest of the 8 villages did not make the Village Property Wealth (KMD) reports. UU The same reason was conveyed by informant due to the limited human resources in the village and according to them, Village Property Wealth Report was too complex to make. As known, the Village Property Wealth Report displayed information about the position of village finance relating to assets, net worth on certain dates, and short-term liabilities. The KMD report displayed the addition of Village Owned Wealth on a particular date. Presentation of KMD Report compared to the previous year to find out the increase or decrease. The previous rule has not mandated the KMD Report, for that the first step in preparing the KMD Report was by investing in net assets and wealth. The Village Law Section 4 Article 116 mandated the district or city government in listing the village assets since the Village Law applied no later than 2 (two) years. This meant that the village should have made an inventory by 2016 at the latest.

Table 13. Reporting and Accountability

\begin{tabular}{llccc}
\hline \multirow{2}{*}{ No } & Explanation & \multicolumn{3}{c}{ Answer } \\
\cline { 2 - 4 } & A & $\begin{array}{l}\text { The village head conveyed to the Regent or Mayor: } \\
\text { 1. Realization report of Village Budget (APBDesa) }\end{array}$ & & Notal \\
\hline & $23(88 \%)$ & $3(12 \%)$ & $26(100 \%)$ \\
implementation each semester & 2. Village Property Wealth Report & $18(69 \%)$ & $8(31 \%)$ & $26(100 \%)$ \\
& & $15(58 \%)$ & $11(42 \%)$ & $26(100 \%)$ \\
3. Program reports that entered the village & & & \\
B $\quad \begin{array}{l}\text { Information to the public related to Accountability } \\
\text { Report of Village Budget Implementation Realization }\end{array}$ & $20(77 \%)$ & $6(23 \%)$ & $26(100 \%)$
\end{tabular}

Source: Research Data, 2016

Regarding the obligation of the village head to convey to the Regent or Mayor if there was a government program to be implemented in the village, only 15 villages that reported and the remaining 11 villages did not report. This was due to 11 villages stated in the discussion that they had no other activities other than programs that have been formally known by the Regent. This indicated the awareness and ability of the village to prepare the financial statements and report them dominating so that the village government could implement the financial administration orderly. Even though the survey conducted by BPS in 2013 also mentioned the obstacles faced 
in making village financial statement largely due to limited human resources capacity, lack of guidance, and lack of adequate training.

With regard to transparency to the community, the accountability for the realization of Village Budget informed directly to the community was carried out by 20 villages through leaflets, meetings and village meetings and the remaining 6 villages did not do so. When it further explored to the village head why this was not done, some gave the same answer that was limited resources and some people thought that the community has known indirectly through the activities that have been running. Nevertheless, there was also an answer that if the information was submitted too broadly, will encourage irresponsible parties to look for problems.

Table 14. Submission of Village Funds Report

\begin{tabular}{lccc}
\hline \multirow{2}{*}{ Explanation } & \multicolumn{2}{c}{ Answer } \\
\cline { 2 - 3 } & Yes & No & Total \\
\hline $\begin{array}{l}\text { The report on the realization of the use of Village } \\
\text { Fund Stage I in 2015 has been delivered on time. }\end{array}$ & $22(85 \%)$ & $4(15 \%)$ & $26(100 \%)$ \\
$\begin{array}{l}\text { The report on the realization of the Use of Village } \\
\text { Fund Stage II in 2015 has been delivered on time. }\end{array}$ & $20(77 \%)$ & $6(23 \%)$ & $26(100 \%)$ \\
$\begin{array}{l}\text { The report on the realization of the use of Village } \\
\text { Fund in 2015 has been delivered on time. }\end{array}$ & $22(85 \%)$ & $4(15 \%)$ & $26(100 \%)$ \\
$\begin{array}{l}\text { Has there been any delay in the distribution and / } \\
\text { or inaccurate amount of distribution }\end{array}$ & $11(42 \%)$ & $15(58 \%)$ & $26(100 \%)$ \\
$\begin{array}{l}\text { Is there still remaining fund in 2015 in Village Cash } \\
\text { Account }\end{array}$ & $3(12 \%)$ & $23(88 \%)$ & $26(100 \%)$ \\
\hline
\end{tabular}

Source: Research Data, 2016

Government Regulation No. 60/2014 that regulated village funds financed by State Budget. Articles 24 and 25 set the details on the aspects of village fund reporting that must be done by the villages. Table 13 below showed how far the compliance aspect of reporting has been done by the villages that became the object of this study. With regard to the report on the realization of Village Fund stage 1 in 2015, there were 22 villages that have submitted their reports on time and 4 other villages have not.

In the second stage realization report, there were 20 villages that have submitted its report to the district and the other 6 villages have not yet or have not reported on time. Furthermore, for the reporting of realization in the use of Village Fund Year 2015 there were 22 villages that delivered the report on time and the remaining 4 villages have not reported on time. Article 25 paragraph (1) stated that in the case of the Head of Village which was not (late) in the submission of the report in accordance with the meaning of Paragraph 2 of Article 24, the regent or mayor may postpone the disbursement of village funds if the realization report in the use of the Village Fund has not reported. Therefore, the delay of village in delivering the realization report would obviously affect the delay of the programs implementation in the next semester, although there has been no immediate sanction applied when this happened.

When asked whether there had been any delay or inaccuracy in the number of distribution, 11 villages claimed to have experienced delays / inaccurate in the amount of Village Fund distribution. Most informants said the reason for the delay due to administrative problems that have not been settled, while others said did not know for sure the cause of the delay. With regard to whether there were remaining Villages Fund of 2015, from 26 villages that became the object of this research, there were 3 villages that claimed to still have the rest of the village funds from the previous year. When asked the amount they did not mention, just stated that the fund was not 
much and the fund came from unrealized activities. The existence of village funds that were not distributed had an impact on the delays of fund disbursement in the next stage which resulted in the planning and implementation of village development was also hampered.

\section{Composition of Village Expenditure}

The existence of village funds that were not distributed had an impact on the delays of fund disbursement in the next stage which resulted in the planning and implementation of village development was also hampered. Besides looking at how financial management of the Village Fund was, this study also tried to see village compliance in allocating Village Expenditure under Government Regulation Number 47/2015 Article 100 stated that Village Expenditure set through Village Budgets could be used if it met the requirements of at least 70 percent from the total village budget which could be used for funding management in government, implementation for development, community empowerment and community guidance; and at most 30 percent from the total village budget could be used to pay the income and allowances of village head, village apparatus and BPD, village government operations and BPD and RT / RW incentives. Furthermore, the data described on the percentage of funds used for the two categories of financing undertaken by the village.

\section{Composition of Village Expenditure ( 70 percent)}

From the data it turned out that there was no one village that the cost of management, the implementation of village government and community guidance reached $70 \%$ as regulated in Government Regulation Number 47 / 2015. The highest percentage for the cost of implementation, the implementation of village government, and community guidance achieved by Tanjung Lubuk Village, Indaralaya Selatan Subdistrict amounted to $62,1 \%$ and the lowest was Payakabung Village, Indralaya Utara Subdistrict equal to $46.7 \%$. The 70 percent of fund should be aimed at the implementation of activity and development of village scale adjusted with work plan compiled and discussed with community empowerment as its priority.

Table 15. Percentage of Funds Based on Financing Group of Community Empowerment (Group I) and Operational (Group II)

\begin{tabular}{llcc}
\hline Village & Subdistrict & $\begin{array}{c}\text { Group I } \\
(70 \text { ` })\end{array}$ & $\begin{array}{c}\text { Group II } \\
(30 \text { `\% }\end{array}$ \\
\hline Tebing Gerinting Selatan & & 53.8 & 46.2 \\
Tanjung Lubuk & Indralaya Selatan & 62.1 & 37.9 \\
Tebing Grinting Utara & & 53.5 & 46.5 \\
Sungai Buaya & Pemulutan & 57.5 & 42.5 \\
Simpang Pelabuhan Dalam & & 57.9 & 42.1 \\
Arisan Jaya & Pemulutan Barat & 57.1 & 42.9 \\
Kapuk & Pemulutan Selatan & 54.9 & 45.1 \\
Payakabung & Indralaya Utara & 46.7 & 53.3 \\
Tanjung Seteko & & 53.7 & 46.3 \\
Saka Tiga Sebrang & & 55.8 & 44.2 \\
Tanjung Sejaro & & 53.3 & 46.7 \\
Penyandingan & Indralaya & 54.1 & 45.9 \\
Muara Penimbung Ulu & & 53.6 & 46.4 \\
Lubuk Sakti & & 53.1 & 46.9
\end{tabular}




\begin{tabular}{|c|c|c|c|}
\hline Tanjung Harapan & \multirow{6}{*}{ Tanjung Raja } & 58.1 & 41.9 \\
\hline Ulak Kerbau Baru & & 57.7 & 42.3 \\
\hline Belanti & & 53.0 & 47.0 \\
\hline Talang Balai Baru I & & 51.9 & 48.1 \\
\hline Tanjung Raja Selatan & & 51.2 & 48.8 \\
\hline Ulak Kerbau Lama & & 50.4 & 49.6 \\
\hline Kerinjing & \multirow{6}{*}{ Payaraman } & 58.9 & 41.1 \\
\hline Tanjung Lalang & & 59.1 & 40.9 \\
\hline Sri Kembang III & & 57.1 & 42.9 \\
\hline Lubuk Bandung & & 59.4 & 40.6 \\
\hline Rengas II & & 57.1 & 42.9 \\
\hline Sri Kembang I & & 58.6 & 41.4 \\
\hline
\end{tabular}

Source: Research Data, 2016

Emphasized on community empowerment for the improvement of government service must also be considered not only the physical development of the village offhand. Along with the development of era, human resources quality should increase, namely by empowering the community. This was due to empowering the community became an important thing in Village Fund Allocation (ADD)'s policy, as so far the existing development has focused on physical development, such as road hardening, building bridges and so on. This indicated a decrease in quality in the management of village budgets because there were still many expenditures in the budget have not been used for activities in accordance with the program that should have been running. In Regent regulations that showed the technical implementation of ADD regulated how the amount in allocating funds showed that the implementation was done in Ogan Ilir District was an activity that was specific grant. The need to build a village varied greatly, the funds set out to be the specific grant brought about similarities in the using funds which had implication of the inequality associated with the needs of each village.

\section{Composition of Village Expenditure (30 percent)}

Government Regulation Number 47/2015 has regulated the allocation of village expenditure, in which the percentage of distribution was 70 and 30 percent. The 30 percent allocation with the data in the field gave an overview of the amount of the costs incurred by the village. These costs used for the needs of the village head and officials' income and allowances, the operations of village government, the BPD allowances, and the RT / RW incentives ranging from Rp 46,800,000 to $\mathrm{Rp} 66,600,000$.- with an average village expenditures equal to $\mathrm{Rp} .54,240,211.54$. The highest village expenditure was Payakabung Village, Indralaya Utara Subdistrict with a total budget of Rp. 66,600,000. Meanwhile, Penyandingan Village, Indralaya Subdistrict had expenditures for the same activities with the smallest value of Rp. 46,800,000, -.

Financing aimed at village income, allowances, incentives, and operations which according to Government Regulation no. 47/2015 was only allowed by 30 percent but in reality all the villages in the Ogan Ilir District that became the object of this research exceeded from the rules set. The highest village in paying income, allowances, incentives and operational were Payakabung Village, Indralaya Utara Subdistrict amounted 53.3\% and the lowest was Tanjung Lubuk Village, Indaralaya Selatan Subdistrict equal to $37.9 \%$.

The ideal composition that has not yet been achieved in the case of village financing would have an impact on development because the existing funds were mostly used for village operational activities and village head or village apparatus allowances as compared to government administration or village development. The average fund for such activities was Rp. 67,115,384.62. 
The village with the smallest expenditure was Payakabung Village, Indralaya Utara Subdistrict amounting to Rp. 54.3 million. The village with the biggest expenditure was Tanjung Lubuk Village, Indralaya Selatan Subdistrict with a total of Rp. 80,650,000, - .

To see more clearly the composition of each village could be seen in Table 14 which gave an overview of the percentage of available funds use. All the villages for village expenditure with 70 percent allocation was still very low, while village expenditure with 30 percent allocation even exceeded from the ideal composition. This indicated that there was a tendency in village financial management to be less understood about cost awareness (awareness of public money), so concrete steps must be taken to build this awareness not only for village officials but also for society in general.

\section{CONCLUSIONS}

The implementation of financial management conducted in the village that become the object of this research has been in accordance with what is regulated in the Minister of Domestic Affairs Regulation No. 113/2014. The Guidelines of Village Financial Management which covers the planning, budgeting, administration, reporting, accountability and oversight stages have been implemented and increasingly villages that are able and obedient to the rules of the village financial system preparation. In the implementation, all village expenditures and revenues are in accordance with applicable procedures. The submission of activities is accompanied by a Budget Plan (RAB) which is verified and approved by the village secretary.

The common priority policy of Village Funds is used to meet basic needs, potential local economic development, and development for village facilities and infrastructure. Regarding the aspects of financial management in general can be said that the implementation of financial management conducted in the village that became the object of research has been in accordance with what is stipulated in the Minister of Domestic Affairs Regulation no. 113/2014 and has complied with the basic principles of financial management. With regard to the administration aspect in general almost all the villages have been able to run the administration aspect well. Reporting and accountability are still a problem for some villages, due to the limitations associated with human resources that master aspects of reporting and accountability. In relation to the composition of village expenditure, all of the studied villages does not meet the composition of village expenditure in accordance with the rule that 70 percent used to finance the implementation of village governance, the implementation in development, community guidance, and community empowerment versus 30 percent from the total village budget expenditure used for income and allowances for village heads and apparatus, village government operations, BPD allowances, and RT / RW incentives. This resulted in inequality in the implementation of development in the village so as not to provide multiplier effects for villagers in development.

This research recommends what can be expected and implemented so that the use of Village Funds can play an important role in the process and distribution of development, namely the need to develop priority stages that will guide the village to determine the priority of the most important and useful activities to be funded by using the Village Fund. In order to improve financial management accountability of the Village Fund, it is necessary to monitor and evaluate in order to improve the accountability of the Village Fund. The need for improved human resource capacity in villages particularly related to the financial management capabilities that must be undertaken to bring about responsible development in rural areas.

\section{REFERENCES}

Abidin, M. Z. (2015). Tinjauan atas Pelaksanaan Keuangan Desa dalam Mendukung Kebijakan Dana Desa. Jurnal Ekonomi Dan Kebijakan Publik, 6(1), 61-76.

Azwardi, \& Sukanto. (2014). Efektivitas Alokasi Dana Desa (ADD) dan Kemiskinan di Provinsi Sumatera 
Selatan. Jurnal Ekonomi Pembangunan, 12(1), 29-41.

BPS. (2015). Kabupaten Ogan Ilir dalam Angka. Ogan Ilir.

Chomariyah, C., Ariyanto, B., \& Hudi, N. (2016). Participation Principle On The 2014 Village Law In Coastal Village. International Journal of Business, Economics and Law, 10(4), 33-41.

Darmada, D. K., Atmadja, A. T., \& Sinarwati, N. K. (2016). Kearifan Lokal Pade Gelahang dalam Mewujudkan Integrasi Akuntabilitas Pengelolaan Keuangan Organisasi Subak. Jurnal Akuntansi Multiparadigma, 7(1), 51-60.

Darmiasih, N. K., Sulindawati, N. L. G. E., \& Darmawan, N. A. S. (2015). Analisis Mekanisme Penyaluran Alokasi Dana Desa (Add) Pada Pemerintah Desa (Studi Kasus Desa Tri Buana, Kec.Sidemen, Kab. Karangasem). Jurnal S1 Ak Universitas Pendidikan Ganesha, 1(3), 1-12.

I Wayan Saputra. (2016). Efektivitas Pengelolaan Alokasi Dana Desa Pada Desa Lembean Kecamatan Kintamani, Kabupaten Bangli Tahun 2009-2014. Jurnal Jurusan Pendidikan Ekonomi (JJPE), 6(2), $1-10$.

Nyimas Latifah Letty Aziz. (2016). Otonomi Desa Dan Efektivitas Dana Desa. Jurnal Penelitian Politik, 13(2), 193-211.

Olken, B. A. (2007). Monitoring Corruption: Evidence From a Field Experiment in Indonesia. Journal of Political Economy, 115(2), 200-249.

Selman, P. (2004). Community Participation in The Planning and Management of Cultural Landscapes. Journal of Environmental Planning and Management, 47(3), 365-392.

Sudaryana, B. (2017). The Effect of Implementation of Rural Development Policy of the Village Welfare in Indonesia (A Case Study in the Villages in West Bandung Regency). International Journal of Applied Business and Economics Research, 15(10), 155-168.

Suparman, Kusnadi, D., \& Harono, D. (2014). IMPLEMENTASI PROGRAM ALOKASI DANA DESA DI KECAMATAN SUKADANA KABUPATEN KAYONG UTARA. Tesis PMIS-UNTAN-PSIAN, 1-20.

Thomas. (2013). Pengelolaan Alokasi Dana Desa dalam Upaya Meningkatkan Pembangunan di Desa Sebawang Kecamatan Sesayap Kabupaten Tana Tidung. Journal Pemerintahan Integratif, 1(1), 51-64.

Peraturan Pemerintah Republik Indonesia Nomor 43 Tahun 2014 Tentang Peraturan Pelaksanaan UndangUndang Nomor 6 Tahun 2014 Tentang Desa. (2014).

Peraturan Pemerintah Republik Indonesia Nomor 60 Tahun 2014 tentang Dana Desa yang Bersumber dari Anggaran Pendapatan dan Belanja Negara. (2014).

Suparman, Kusnadi, D., \& Harono, D. (2014). Implementasi Program Alokasi Dana Desa Di Kecamatan Sukadana Kabupaten Kayong Utara. Tesis PMIS-Untan-Psian, 1-20.

Thomas. (2013). Pengelolaan Alokasi Dana Desa Dalam Upaya Meningkatkan Pembangunan Di Desa Sebawang Kecamatan Sesayap Kabupaten Tana Tidung. Jurnal Pemerintahan Integratif, 1, 51-64. 